\title{
Small Rural Schools: Unique Challenges, Unequal Treatment -- A Policy Analysis
}

\author{
V. Sue Atkinson ${ }^{1}$ \\ Binghamton University
}

Ignored under No Child Left Behind (2002) and given only lip-service in the 2015 Every Student Succeeds Act (US Department of Education, 2021), rural schools face challenges of poverty as well as inequities in the form of discrimination under current Title I funding allocation formulas and disproportionate location in states with low levels of school aid. Furthermore, rural areas, and hence rural schools, face challenges of declining population and school enrollment, consolidation pressures, and an eroding economic base that is both a cause and an effect of youth out-migration. The problems of rural areas and rural schools are stereotyped, ignored or exploited by policymakers, and invisible to much of the public (Lichter \& Parisi, 2009). Consequently, rural schools continue to be underserved by current education policies and initiatives, and their students left behind.

A common image of struggling schools and neglected students is described by Jonathan Kozol (2005) in Shame of the Nation: decaying school buildings in a central city attended by students of color who live in dangerous, drug-infested neighborhoods in female-headed, singleparent households dependent on public assistance. However, a significant number of schools attended by children who live in poverty do not fit this description. Poverty in rural areas and rural school districts is prevalent and persistent. A higher percentage of rural families are poor (15\%) compared to urban families (12.5\%). This has been true every year since 1960, as most geographic areas of highly persistent poverty are rural (Annie E. Casey Foundation, 2008; Jensen, 2006), and 48 of the 50 counties with the highest poverty rate are rural. These numbers

\footnotetext{
${ }^{1}$ V. Sue Atkinson, corresponding author, atkinson@binghamton.edu
} 
rise during economic recessions, and recent Census Bureau figures show 29\% of young children in rural areas living poverty (Mattingly \& Stransky, 2010).

Equity in funding children's education is a concern in rural education, just as it is for schools in urban areas. Kozol (2005) compares per pupil spending in rich and poor school districts, poignantly describing a poor, urban black child as having a price tag of $\$ 11,700$ (p. 45), a "Kmart child" (Kozol, 2007 interview) and a suburban child as having a price tag of \$22,000, a "Saks Fifth Avenue child." In Kozol's writings, these "Kmart children" live in urban core areas plagued by poverty and racism, and attend segregated, dilapidated, and ignored schools. But there is another group we might call "Walmart children," the rural poor. Although on average, rural schools spend more per pupil than urban schools, though less than suburban schools), high poverty rural schools spend even less per pupil than high poverty urban schools (NCES, 2007; Rural School and Community Trust, 2007).

While the majority of poor children in rural schools are white, depending on the part of the country that is being studied, rural poverty looks quite different. "If you live in Appalachia, rural poverty looks white; if you live in the Mississippi Delta, rural poverty looks black; if you live in the Rio Grande Valley, rural poverty looks Hispanic; and if you live in the Dakotas, American Indians make up the bulk of the rural poor" (O’Hare \& Johnson, p. 8).

Poor rural people of color are poorer on average than are poor rural whites (Huang \& Howley, 1991). Children of color living in rural areas truly are in double jeopardy. They are even more likely to attend a high-poverty school than rural students as a whole, and $87 \%$ of rural black students attend high poverty schools compared to $78 \%$ of urban black students. Furthermore, rural black residents are more segregated in high poverty communities than are urban blacks (Lichter \& Parisi, 2008). 


\section{Rural Schools-Struggling to Do Well, but Not Getting Their Due Who Advocates for Rural Schools and Communities?}

Every institution, policy, and practice - especially those that now dominate education and larger society — establish relations of power in which some voices are heard and some are not. Although it is not preordained that those voices that will be heard most clearly are also those who have the most economic, cultural, and social capital, it is most likely that this will be the case. (Apple, 2005, p. 229)

Rural residents are in a uniquely difficult situation in advocating for their needs. In addition to sparse population, low total numbers, and a tradition of rugged individualism and reliance on family and community, many live in areas that are represented by Republican and conservative legislators who have traditionally not supported social programs that would benefit the rural poor. Neo-conservatives (Apple, 2006), while viewing favorably the idealized rural lifestyle of hard work, thrift, clean living, and closeness to nature, view rural poverty as the result of individual choices and reaction to one's surroundings. They believe that people are poor because of a human capital deficit, however, most poor rural adults work, but they are still poor (Huang \& Howley, 1991; O’Hare \& Johnson, 2004). Rural areas are plagued by high unemployment and low incomes, putting this framework of individual choice and blame in question. In contrast, a structural view of rural poverty focuses on place, seeing poverty as created by economic and environmental factors (Fitchen, 1991; Rural Poverty Research Institute, 2009).

It appears that overwhelming support of Republican and conservative politics works against the interests of the rural poor, and rural residents in general; Apple (2006) reminds us that history plays a role. He tells of working class rural residents rejecting Darwinism and 
accompanying beliefs and politics as something for the upper class, the educated class, people who looked down on them. These people proudly termed themselves "rednecks," people who did real work, as opposed to "pale and wan elitist and affluent upper classes" (p. 133). Rural residents represent people whom Apple describes as attracted to the anti-elitist face of authoritarian populism as well as the tradition-honoring face of neo-conservatism.

Rural poverty also suffers from an extremely low profile. When "welfare reform" was implemented in the 1990s, a study of 1400 newspaper articles on the topic found that none mentioned rural welfare recipients (O’Hare \& Johnson, 2004). Rural schools also go largely unnoticed. In 2001, of 264 "Blue Ribbon Schools," a US Department of Education program that recognizes schools based on academic performance (USDE, 2020), 46\% of which were lowincome, only 5\% were rural (Bassett, 2003).

\section{Rural Schools_-Doing Well Overall, but Concerns Persist}

Test data for rural schools paint a deceptively positive picture. More rural students score proficient on the National Assessment of Educational Progress (NAEP) in reading, math, and science than do students in urban schools, though they score lower than do suburban students (National Center for Education Statistics (NCES), 2007). Rural schools overall have a graduation rate of $75 \%$, almost equal to suburban schools at $79 \%$, and higher than urban schools with a rate of $65 \%$. However, the poorest rural schools (studied and tracked as the "Rural 900," primarily located in the south and the southwest) have higher dropout rates than rural schools overall. These schools enroll more minority children than rural schools with higher graduation rates (Johnson et al., 2010). In addition, remote rural schools (defined as schools that are 35 or more miles from a population center) have lower NAEP scores than other groups (NCES, 2007). 
These contrasting findings result from NCES data that averages rural data, including some urban fringe communities that are well off, as well as more remote rural schools. This masks some problems, and it consistently places rural schools in the middle, not performing as well as suburban schools, but better than urban schools. A more refined look at remote rural schools shows lower performance and more reason for concern (Rural Matters, 2007).

\section{Unique Challenges, Unequal Treatment}

Rural schools are largely expected to fit the mold of programs designed for suburban or urban areas, and are not well served by current education policy, as the supposed reforms of No Child Left Behind (NCLB) and the 2015 Every Student Succeeds Act (ESSA; US Education Department, 2021) largely continue to impose an urban model on small rural schools (Eppley, 2009; Khattri et al., 1997; O’Hare \& Johnson, 2004). The National Rural Education Advocacy group has been critical of NCLB because it provided insufficient assistance for rural schools (Kirst \& Wirt, 2009). Rural school advocates have long pointed out that reforms outlined in NCLB were a poor fit for rural schools, which lack capacity and resources to implement reforms (Arnold, 2004). The prescribed remedies and sanctions make no sense in small rural districts, which cannot implement school closure, staff replacement, or conversion to charter because the community's children would have no school to go to (Howley, 2010). Firing teachers at "failing schools" will not help students such as those in remote areas of Alaska whose schools can barely attract qualified teachers now (Dillon, 2010), and in fact, researchers question the fit of NLCB's "highly qualified" requirements for rural schools as insufficiently nuanced and lacking regard for context (Eppley, 2009).

While ESSA (2021), the latest version of the Elementary and Secondary Education Act (ESEA), addressed some issues raised by rural advocates, it failed to address the largest fiscal 
inequity in funding for rural schools serving poor children. Since 2002, Title I allocation formulas have unfairly penalized small school districts. Title I funds (federal funds for schools serving disadvantaged children under ESEA) are allocated by formulas that shortchange small rural schools with high poverty. Schools can choose a formula based on the total number of poor students (number weighting), in contrast to percentage weighting, which bases per-child aid on the percentage of poor children in a district. Number weighting provides more money to large districts, poor or not, than to small schools with high poverty (Rural School and Community Trust, 2010; US General Accounting Office, 2002). This means that larger schools with a lower percentage of poor children receive more aid per poor child than smaller schools with higher poverty. Fairfax County, Virginia schools, with a 5.5\% eligibility rate, receive $\$ 1935$ per formula student; Lee County, Virginia schools, with a 37.7\% eligibility rate, receive $\$ 1488$ per formula student (Strange, 2010).

Compounding the funding loss due to bias in favor of population density over poverty as criteria for funding, schools that lose out on higher Title I funding due to number weighting are disproportionally located in districts and states that already have low spending on education (US Census Bureau, 2009). Because Title I aid is also dependent on the overall level of state aid to schools, schools in states that fund education at lower rates are further disadvantaged (Rural School and Community Trust, 2010).

In Shame of the Nation, Kozol (2005) movingly describes a child whose education is funded at a low level, and invites us to imagine "scooping up" that child and putting her down in a more affluent district, with that simple move resulting in a higher price tag on that child's education (p. 45). Title I funding works the same way for some children. A poor child in Boston, a large district located in a state that funds education at a comparatively high level, nets her 
district \$2495, while the same child, if transported to Macon County, Alabama, would net only $\$ 1280$ for her school despite that school's higher poverty rate (Rural School and Community Trust, 2010).

The federal government allocates a fixed amount of Title I funds each year, so if one district gets more, another gets less, setting the scene for competition among districts serving children in poverty while wealthier districts remain above the fray.

\section{Rural Schools--Rural Communities}

Just as factors outside of school, primarily poverty, have a profound impact on the schools' ability to eliminate student performance gaps single-handedly (Rothstein, 2008), rural schools and their students' needs reflect larger issues of rural communities. In fact, community impact on achievement may be greater in rural schools (Boilieu et al., 2003).

Rural residents have faced challenges throughout our country's history. While history books tell of brave settlers on the frontier, supported by government land grants, there is another story--of continued attempts by the ruling class to contain those settlers and keep them as an underclass. Domhoff $(2005$, p. 1) wrote that "those who own income producing propertycorporations, real estate, agri-business — set the rules within which policy battles are waged. From Shay's Rebellion in 1786, when the armed forces of our new nation were used to protect landowners' rights to foreclose on the farms of unpaid Revolutionary War veterans, to the AntiRent Wars in upstate New York in the $19^{\text {th }}$ century, in which local resident farmers protested a feudal system of excessive land rents that dated from the days of the Dutch patroons, to crop liens in the western territories and a monetary policy that kept settlers literally "dirt poor" (Theobald, 1997), the national and state policy has favored business interests over those of rural residents. 
Populism nowadays is equated in popular media with bigotry and intolerance, but in the late $19^{\text {th }}$ century, the populist movement represented rural residents' desire to shape national policy that attended to the interests of producers as well as commercial interests (Apple, 2006). This movement was "the last forthright attempt by rural dwellers to put the country on an equitable course, on a trajectory that would attend to the interests of the producers as well as those of the commercial interests" (Theobald, 1997, p. 97). After losing the battle over monetary policy, the movement dwindled, the Democratic party turned to corporate liberalism, and farmers lost out.

In early $20^{\text {th }}$ century, migration from farm to city became a widespread concern. "The city sits like a parasite, running out its roots into the open country and draining its subsistence," wrote Liberty Hyde Bailey (Theobald, 1997, p. 103), whose Cornell University-based Country Life Movement aimed to educate students about their rural heritage, and connect their schooling to their farm life, nature, and environmental studies (Kliebard, 2004), preaching the virtues of country over city life, in an effort to keep the "best and brightest" (Theobald, 1997, p. 105) on the farm.

By 1920, efforts to keep young people "down on the farm" had been abandoned, and the percentage of adults earning a living from farming shrank from $40 \%$ to less than $2 \%$ in 2000 (Wood, 2008). Farm policies consistently supported big farming and agri-business over family farms, with huge land grants to the railroads, railroad pricing structures that favored grainelevator operators over local distribution of crops, and more recently, federal farm policies that cause alternating surpluses and shortages. Artificially low commodity prices drove farmers out, or forced larger and larger operations, with huge debt burdens that then disadvantaged farmers when monetary policy favored creditors. 
Similar to the decline experienced in urban areas, rural areas continued to decline as suburban growth was subsidized politically and economically in the 1950s, for example, the 1956 National Defense Highway System (Spring, 2005). Now, after more than 100 years of supporting corporations over farmers, neo-liberals "sell despotism and avarice as freedom and democracy" (Berry, 1978, p. 11), advocating choice and free-market principles (with some glaring exceptions within current agricultural policy) that keep agricultural prices low, cause an exodus of business and jobs, and give rural families choices that have resulted in a brain drain and a youth drain on rural areas. Rural advocates cite free-market capitalism as a cause of rural decline (Wood, 2008).

\section{Declining School Enrollment and Consolidation}

The number of children in many rural schools has decreased over the past several decades, in some areas causing a crisis in the schools as enrollment drops precipitously. One often-proposed solution to declining enrollment is consolidation, or joining two or more small school districts together. This free-market-type solution to the problems of rural schools would simply make the schools bigger, and in fact, consolidation of very small districts is promoted as a cost-effective way to address many problems of poor rural schools (Duncombe \& Yinger, 2005, p. 2). New York's governor, Andrew Cuomo, a long-time supporter of consolidation as a costsaving measure (Bakeman, 2014), campaigned on a platform that promoted school consolidation and advocated legislation to require districts with fewer than 1000 students to merge with another district, and New York State education policy has promoted the consolidation of small, rural schools since 1958 (Jakubowski \& Kulka, 2016).

While consolidation can result in cost savings due to lower overhead and the ability to share some services, often the savings are as short-lived as this solution is shortsighted. In New 
York, merging districts receive additional state aid for five years, which decreases in subsequent years (New York State Education Department, 2010). Building aid is offered at an attractive percentage of building costs; one result is that districts then find they have new buildings in locations outside small towns or villages, resulting in extensive busing, with rising gasoline costs and extremely long bus rides for students. At the same time, school buildings that once served as the center of small communities sit empty, and property values fall. Schools in rural communities may be one of the few local employers, and may even be a major purchaser of goods and services. These consolidation efforts also contradict research suggesting that smaller schools may be better for students (O’Hare \& Johnson, 2004).

Overall, small rural schools do well for children. Compared to urban school, rural schools have higher test scores, graduation rates, and teacher satisfaction, and lower rates of behavior problems and absenteeism. Small schools are safer, with less violence and less vandalism. And while cost per student is higher than in larger schools, the cost per high school graduate is actually lower (NCES, 2007; Rural School and Community Trust, 2012).

Apple (2006) points out that school reforms often have unintended consequences. Consolidation can negatively affect both rural communities and rural students. State aid incentives last only a few years, transportation costs increase with each rise in gasoline prices, children spend inordinate amounts of time on school buses, communities lose their center, and students lose the increasingly documented advantages of small schools, proving once again that an urban "one best system" (Tyack, 1974) is not best for rural schools (Lockette, 2010; O’Hare \& Johnson, 2004). Small size is an advantage when it means that students interact more frequently with teachers, teachers get to know students better, and students have more opportunities to participate in extra-curricular activities. Parent involvement and partnerships 
between home and school result in better academic outcomes (Boilieu et al., 2003), and build social capital in families, school, and community (Allen, 2007).

\section{Doing Right, but Somehow Getting it Wrong: When Achievement Doesn't Equal Success}

Rural schools serve as the perfect counterpoint to current education policy centering on narrow quantitative measures. Rural students overall do well on tests, and graduation rates have improved in recent years. But this has not brought traditional success to the students or prosperity to their communities; in fact, there is "an immense gap" (Lawrence, 1998, p. 1) between many rural students' test scores and attainment of post-secondary education.. Rural students take fewer college preparatory courses such as calculus or chemistry, and the schools offer fewer AP classes (Arnold, 2004). Parents of rural students have lower expectations for college success than do urban parents (Khattri et al., 1997). Rural students attend college at lower rates than their suburban, or even urban, counterparts, and academically successful rural students are more likely to leave their communities than to remain and enrich them. Colleges are farther away for these students, parents are less likely to have attended, and rural communities include fewer college graduates (NCES, 2007), as many who do go to college do not return.

\section{Brain Drain: Losing Rural Youth}

Out-migration of 20-30 year olds from rural areas is a persistent trend, and young people from rural areas are more likely than urban dwellers to leave the place where they grew up, and to experience more conflict over this decision (Boethel, 2000). While some young people who leave rural areas in search of educational, employment, and social opportunities return to raise families, most do not (O'Hare \& Johnson, 2004). Unlike the migration from rural areas that occurred during the 19th century (Ferrie, 2003), it is now the better educated youth who leave rural areas and lifestyles behind (Heminway, 2002; Huang \& Howley, 1991), placing families in 
the difficult situation of weighing conflicting priorities of wanting their children to follow in their footsteps, and wanting the best for their children. Like all parents, rural dwellers want their children to do well, but know that they risk them leaving the area and their lifestyle behind (Sherman \& Sage, 2011), similar to the youth of ethnic groups who feel they must deny their culture to get ahead, and hence contribute to its destruction. Rural youth, who report feeling "more empty and angry about their futures" (Howley et al., 1996, p. 151) are presented with a difficult choice: "to leave family and land to find a future, or to stay and suffer from low aspirations and a poor self-image" (Heminway, 2002, p. 10). Rural economic development policies that focus on bringing in low wage and low-skill jobs exacerbate this trend (Arnold, 2004).

\section{What are Rural Areas Good For?}

Politicians' approaches to rural areas show neglect, sometimes combined with outright scorn, or a view that rural life is (ironically) unsustainable. In a well-publicized Playboy interview in 1982, former New York City mayor Ed Koch referred to rural life as "a joke," describing it as, "When you have to drive 20 miles in a pick-up truck to buy a gingham dress or a Sears, Roebuck suit” (Soffer, 2010, p. 231). Few politicians today have Koch's candor, but many have attitudes that are not very different. While vocabulary contains few derogatory words for urban residents as a whole, there are many for rural residents_-“crackers, rubes, hayseeds, hicks, hillbillies, bumpkins, peasants, rednecks, yokels, and white trash” (Bassett, 2003, p. 3).

Academia also has not embraced rural issues; in the vast majority of academic writing, poverty is an urban or third world issue. Finally, public opinion of rural dwellers, while admiring of "old fashioned values," also subsumes stereotypes of people who are unsophisticated, "behind the times," "hicks," or "rednecks" (W. J. Kellogg Foundation, 2001, pp.8-9). 
Rural economic development often depends on continued exploitation of not just of the people, but also of their environment. Whether the desired resource is water, coal, minerals, natural gas, or land to site a garbage or hazardous waste dump, or a prison, "rural America has become a dumping ground for the waste products of urban core areas. With the decline in extractive industries, the quality of the environment may be one of the last marketable resources available in many rural communities" (Miller, 1993, p. 100).

Who benefits from under-resourced rural schools and underserved rural poor children? Who loses if rural areas continue to decline, and our country continues to "hollow out the middle?" (Carr \& Kefalas, 2009). Affluent leaders of society enjoy vacationing in rural areas, and a less educated and underemployed population can serve them well. Other urban and suburban residents need rural areas for vacation and personal renewal; they find them a nice place to visit, but they certainly would not want to live there. Aided by comedians exploiting the one subculture that is still socially acceptable to ridicule, some enjoy feeling superior to other white people, as well as to minorities. New York City has essentially colonized upstate New York through watershed takings, subsequent restrictions of economic development upstate, and the threat of widespread drilling for natural gas. A smaller and more docile rural population might make this easier.

\section{Conclusion}

While urban children go to school in decaying buildings, rural communities have perfectly good school buildings standing empty, beginning their own process of decay, mirroring the communities they once centered. While "white flight" has left urban schools segregated, rural schools have children whose needs go unnoticed and unmet because they go to schools where everyone looks deceptively the same. While poor urban black children are trained to become 
consumers, service workers (Kozol, 2005), or docile inmates, rural children are taught to equate success with leaving home, trained to serve the vacationing rich who see rural areas as a nice place to visit, but have no real conception of people actually living there, or disproportionally become cannon-fodder in the latest war (O’Hare, 2007).

Rural schools need policies and resources targeted especially at the poorest, most remote, and most segregated rural schools. They need assistance that takes into account the unique needs of rural communities and their economy, geography, history, and culture.

\section{What Can We Do? Recommendations Going Forward}

In the school district where I reside, the number of students is shrinking every year, in a town where industry has left and a flood depleted affordable housing stock 14 years ago and then again 5 years later, and where the number of students receiving free and reduced-price lunch has doubled in recent years and now stands at almost half the student body. Almost every student's parents work, but many are still poor.

What can be done to help schools like this one? Rural areas, by definition, lack geographic advantage. They are also places where opinions diverge, and authoritarian populism and all types of conservative viewpoints, from neo-conservative to conservative-libertariansurvivalist run strong. I may not share these views, but "a community is a place where people who may not like one another nevertheless work together to advance the welfare of that which they hold in common" (Theobald, 1997, p. 121). Apple (2006) advises those looking to "right wrongs" to "not shun religious discourse and "God talk" (p. 255) but to expand the discourse of morality as it applies to issues such as poverty and social needs, to (carefully) seek common ground, and to find strength in movements such as the evangelical environmental movement. He ascribes the success of right-wing movements in mobilizing and uniting people with apparently 
disparate needs by finding and exploiting small areas of common concern and common language. Rural community members and school advocates need to do the same.

Schools can assume a central role in rebuilding rural communities (Theobald, 1997). Rather than waiting for economic development to rescue communities, schools can be a catalyst. We can learn from history that the false promises of so-called Progressive education-large systems headed by professional administrators who are not educators, emphasis on preparing students for jobs in an ever-changing market that are dependent on mobility and divorced from the place where they are located, and narrow measures of success-hold little for rural communities. Small schools can draw on current pedagogical knowledge that recognizes the importance of background knowledge, culture, and connection to students' day-to-day lives (Allen, 2007). We need to re-culture, not re-structure, rural education to counteract destructive cultural messages that suggest that urban is better than rural, that big is better than small (Theobald, 1997), to resist the "cultural imperialism" (Spring, 2005, p. 26) implied in many approaches to rural issues.

Place-based development aims to capitalize on unique characteristics of a particular place (Morgan et al., 2009). Applied to education, this is the antithesis of standards-based instruction. Schools that are linked to their communities give students a sense of purpose, help make them effective community members, and bring relevance to the curriculum.

In the despairing news about the global economy, we can see glimmers of hope. In some areas, young people are returning to farm in a different way and exploit the new interest in local and organic foods. Nationally, we see movements away from consuming and acquiring gadgets, and climate change concern and action is spreading. In the education arena, parents show dissatisfaction with test-based reforms (O’Callaghan \& Irish, 2006). Allen (2007) writes of 
school and community collaborations in which students, families, teachers, administrators, and community members work together to research and address school and community needs. We can take heart from these stories, and begin to write our own.

\section{Teachers and Administrators:}

1. Capitalize on the fact that although rural teachers earn lower salaries than their urban or suburban counterparts (NCES, 2007; Jimerson, 2003; Rural School \& Community Trust, 2003), they report greater job satisfaction and fewer problems with discipline (NCES, 2007). Rural schools have a lower student: teacher ratio than urban or suburban schools (NCES, 2007). More meaningful teacher-student relationships are real school reform.

2. Know about and teach students their rural heritage and rural history.

3. Engage in community activities such as those in Allen's (2007) Creating Welcoming Schools, but be sensitive, residents may have mixed feelings about publicizing problems.

4. Learn about the implications of child poverty (Garrett, 1996), but even more, learn about the lives of your students. Be sensitive and open to families' situations and backgrounds. "When I'm in the teachers' lounge, I cringe at the way we talk about children..." (Allen, 2007, p. 69). Raise the level of discourse.

5. Take advantage of small schools, small classes, and opportunities for relationships. Don't pretend you're in a big school. See strengths. Know and connect with kids (Ohanian, 1999).

6. Initiate community-based curricula. Students, even those who seem detached, lazy, or unmotivated, can contribute when given something meaningful to do. Community based instruction is "messier and more complicated" (Boethel, 2000, p. 18) but draws on much of what we know is good pedagogy. 
7. Use technology strategically to extend the reach of rural residents in ways that will enrich their lives, diminished isolation, and open up new worlds to rural youth. Technology as a teaching tool, a means of conducting research within the classroom and school, can only enrich the curricular experience of rural students. Technology as a service-delivery method, with instruction delivered via distance learning methods, contradicts much research on the importance of interpersonal relationships in education, and fails to draw on the unique strengths of rural schools (Boilieu et al., 2003).

\section{Guidance Counselors:}

1. Rural high school students are more likely to get college information from school personnel than from their parents. Many students and their parents are unfamiliar with the forms, the language and acronyms, and the timeline of college and financial aid search and application (Bassett, 2003). Take students to visit colleges.

2. Stay with students through the process. Look at their acceptance letters and financial aid packages. Help them understand and interpret financial aid offers. No one at their home may be able to do this. Check in with them over the summer (Arnold et al., 2009).

3. Track and support high school graduates who go to college. Many thrive academically, but have trouble fitting in, especially at urban colleges, or private colleges that enroll the children of the wealthy (Bassett, 2003).

4. Talk to students about careers and opportunities that exist in their local area if they wish to stay or return.

\section{Community Members (and Teachers-Who are Often Both):}

1. Help young people who want to stay in the area. Invest in them, help them, and work with them. Rural communities typically spend most of their effort and resources on kids 
that are not likely to stay, even encouraging them to leave, and under-invest in those who stay (Carr \& Kefalas, 2009). Connect kids with local businesses; this reduces youth outmigration (Khattri et al., 1997).

2. Believe that kids will come back to rural communities if there is something to come back to. As Dorothy discovered in The Wizard of $O z$ when she left her barren Kansas farm life for the glamour of $\mathrm{Oz}$, there really is "no place like home" for many rural residents. ${ }^{2}$

3. Get involved. In many areas, communities have lost the little control they had when school boards were "reformed" and school governance was largely transferred to more centralized boards representing business interests (Spring, 2005). Kirst and Wirt (2009) quote Chester Finn, who claims that school boards are "a dinosaur left over from our agrarian past” (p. 131). While state and federal policies today leave less to local control, rural communities (which are not extinct yet, despite Chester Finn's nescience) still have school boards that represent the community, the opportunity to vote on school budgets, and opportunities for parents and community members to serve on school committees.

\section{Public Officials:}

1. Advocate for fair funding of all schools. The battle is not between one poor district and another.

2. Consider the rural impact (comparable to environmental impact) of every policy.

3. Consider creative alternatives to consolidation: (a) Draw students from a wider age range in order to increase the number of students in a school building, rather than following the trend toward including smaller numbers of grades in a school, as this would narrow the geographic area served by the school building and cut transportation time to and from school. There are social and pedagogical benefits to bringing students of all ages

\footnotetext{
${ }^{2}$ This analogy appears in Wood, Survival of Rural America.
} 
together, as well as benefits from making the school more accessible to the community.

(b) Lease surplus space that may result from lower student population to community agencies such as day care or senior centers, health care centers for students, families, and community members, and business and recreational organizations. (c) Share services and purchase cooperatively while maintaining buildings. Many of the efficiencies attributed to consolidation can be realized without physically relocating children away from their communities (Rural School and Community Trust, 2011).

\section{All Stakeholders:}

1. Be aware that there are obstacles -- turf, money, avoidance of controversy, high value of a façade of collegiality, and factionalism -- within small communities (Boethel, 2000), both the more well-known divide of newcomers and old-timers, and the deeper, stronger, less recognized schism between the small town middle class and the rural poor.

2. Understand that preserving the strengths of rural schools is not a nostalgic attempt to return to a "romanticized past of the 'ideal' home, family, and school" that Apple (2006, p. 55) attributes to the alliance of rightist forces.

Rural communities and schools did not devolve overnight, and they did not devolve on their own — not just neglect, but economic policies and political forces shaped that decline. Those who are genuinely concerned about rural schools must tune out the louder, harsher voices advocating school reform that is divorced from place and unsuited to rural communities. Positive change takes time and support (O'Callaghan \& Irish, 2006) as we work toward the creation of small rural school that are part of sustainable rural communities. 


\section{References}

Allen, J. (2007). Creating welcoming schools. Teachers College Press.

Annie E. Casey Foundation. (2004). Strengthening rural families: The high cost of being poor. http://www.aecf.org/upload/publicationfiles/rf2022k560.pdf

Apple, M. (2006). Educating the "right" way: Markets, standards, God, and inequality (2 ed.). Routledge.

Arnold, K., Fleming, S., DeAnda, M., Castleman, B., \& Wartman, K.L. (2009). The summer flood: The invisible gap among low-income students. Thought \& Action, 25, 23-34.

Arnold, M. (2004). Guiding rural schools and districts: A research agenda. Midcontinent Research for Education and Learning. https://eric.ed.gov/?id=ED484397

Bakeman, J. (2014, December 29) Cuomo, Regents push district mergers, despite challenge. Politico. https://www.politico.com/states/new-york/albany/story/2014/12/cuomo-regentspush-district-mergers-despite-challenge-018482

Bassett, D. L. (2003). Ruralism. Iowa Law Review, 88, 273. https://nationalaglawcenter.org/publication/download/bassett-ruralism-88-iowa-l-rev273-342-2003

Berry, W. (1978). The unsettling of America: Culture \& agriculture. Avon Books.

Boethel, M. (2000). Thriving together: Connecting rural school improvement and community development. Southwest Educational Development Laboratory. ED 451020. https://files.eric.ed.gov/fulltext/ED451020.pdf

Boilieu, L.J., Israel, G. D., \& Wimberley, R.C. (2003). Promoting educational achievement: A partnership of families, schools and communities. In D.L. Brown, \& L. E. Swanson 
(Eds.). Challenges for rural America in the twenty-first century (pp. 273-289).

Pennsylvania State University Press.

Carr, P. J. \& Kefalas, M. J. (2009). Hollowing out the middle: The rural brain drain and what it means for America. Beacon Press.

Center for Rural Affairs (2008, September 9). Ability of rural areas to retain and attract youth dependent on local ownership. http://www.organicconsumers.org/articles/article_14545.cfm

Dillon, S. (2010, March 17). Lawmakers say needs of rural schools are overlooked. New York Times. https://www.nytimes.com/2010/03/18/education/18educ.html

Domhoff, G. W. (2014). Who Rules America (7 ${ }^{\text {th }}$ ed.). McGraw Hill.

Duncombe, W. \& Yinger, J. (2005). Does school district consolidation cut costs? Center for Human Policy, Syracuse University. https://www.maxwell.syr.edu/uploadedFiles/cpr/research/cpr_research_education_financ e_policy/Does_School_Consolidation_Nov_05.pdf

Eppley, K. (2009). Rural schools and the highly qualified teacher provision of No Child Left Behind: A critical policy analysis. Journal of Research in Rural Education, 24(4). http://jrre.psu.edu/articles/24-4.pdf

Ferrie, J. P. (2003). How ya gonna keep 'em down on the farm [when they've seen Schenectady]?: Rural to urban migration in the U.S., 1850-60. Working Paper. http://faculty.wcas.northwestern.edu/ fe2r/papers/urban.pdf

Fitchen, J. M. (1991). Endangered spaces, enduring places: Change, identity, and survival in rural America. Westview Press. 
Garrett, P. (1996). Poor kids in a rich nation: Eating the seed corn. ED 406080. https://files.eric.ed.gov/fulltext/ED406080.pdf

Heminway, M. T. (2002). Maine's Disappearing Youth: Implications of a Declining Youth Population. Maine Leadership Consortium.

Howley, C.B., Harmon, H.L., \&.Leopold, G.D. (1996). Rural scholars or bright rednecks? Aspirations for a sense of place among rural youth in Appalachia. Journal of Research in Rural Education, 12(3),150-160.

Huang, G. \& Howley, C. (1991). Recent trends in rural poverty: A summary for educators. ED 335 180. https://www.ericdigests.org/pre-9221/recent.htm

Jensen, L. (2006). At the razor's edge: Building hope for America's rural poor. Rural Realities, 1(1).

Jimerson, L. (2003). The competitive advantage: Teacher compensation in rural America. Policy Brief, Rural School and Community Trust, 2003 ED 474248. https://eric.ed.gov/?id=ED474248

Johnson, J., Strange, M., \& Madden, K. (2010). The rural dropout problem: An invisible achievement gap. Rural School and Community Trust. https://files.eric.ed.gov/fulltext/ED516681.pdf

Jakubowski, C., \& Kulka, L. (2016). Overcoming state support for school consolidation: How schools in the Empire State react. Journal of Inquiry \& Action in Education, 8(1), 66-80.

Khattri, N., Riley, K. W., \& Kane, M. B. (1997). Students at risk in poor, rural areas: A review of the research. Journal of Research in Rural Education, 13 (2) 79-100. 
Kirst, M. W., \& Wirt, F. M. (2009). The political dynamics of American education (4 ${ }^{\text {th }}$ ed.). McCutchan Publishing.

Kliebard, H. M. (2004). The struggle for the American curriculum. RoutledgeFarmer.

Kozol, J. (2005). Shame of the nation: The restoration of apartheid schooling in America. Three Rivers Press.

Kozol, J. (February 10, 2007). Interview at Jabberwocky Book Shop, Newburyport MA [Video file]. http://www.youtube.com/watch?v=7VS9XHbEaFY

Lawrence, B. K. (1998). Working memory: The influence of culture on aspirations. ED 430 765. https://files.eric.ed.gov/fulltext/ED430765.pdf

Lichter, D. T., \& Parisi, D. (2008) Concentrated rural poverty and the geography of exclusion. Rural Realities/Rural Sociology Society, University of New Hampshire. https://scholars.unh.edu/cgi/viewcontent.cgi?article=1054\&context=carsey

Mattingly, M. J. \& Stransky, M. L. (2010). Young child poverty in 2009: Rural poverty rate jumps to nearly 29 percent in second year of recession. Carsey Institute Issue Brief 17. https://scholars.unh.edu/carsey/120/

Miller, B.A. (1993). Rural distress and survival: The school and the importance of “community.” Journal of Research in Rural Education, 9(2), 84-103.

Morgan, J.Q., Lambe, W., \& Freyer, A. (2009). Homegrown responses to economic uncertainty in rural America. Rural Realties, 3(2) 1-15. http://ruralsociology.org/StaticContent/Publications/Ruralrealities/pubs/RuralRealities32.pdf 
National Center for Education Statistics (July 25, 2007). Status of Education in Rural America. NCES \# 2007040.

http://arsl.pbworks.com/f/Status+of+Education+in+Rural+America+2007.pdf

New York State Education Department, The University of the State of New York. (2010). New York State Board of Regents Proposal on State Aid to School Districts For School Year 2010-11. http://www.p12.nysed.gov/stateaidworkgroup/2010-

11RSAP/RSAP1011final.pdf

No Child Left Behind Act of 2001, Pub. L. No. 107-110. (2002). 115 STAT. 1425. http://www2.ed.gov/policy/elsec/leg/esea02/107-110.pdf

O’Callaghan, W. G. \& Irish, C. M. (2006). The right place, the right TIME. School Administrator, 63(2), 18-24.

O’Hare, W. P. \& Johnson, K. M. (2004). Child poverty in rural America. Population Reference Bureau Reports on America, 4 (1). https://scholars.unh.edu/soc_facpub/71

Ohanian, S. (1999). Once size fits few. Heinemann.

Rothstein, R. (2008) Whose problem is poverty? Educational Leadership, 65 (7).

Rural Policy Research Institute. (2009). Perspectives on poverty, policy, and place. $R U P R I$ Newsletter, 5. https://rupri.org/wp-content/uploads/PerspectivesWinter09.pdf

Rural School and Community Trust. (2011, February 16). Consolidation fight-back toolkit. http://www.ruraledu.org/articles.php?id=2425

Rural School and Community Trust (2012, February 23). Instructional expenditures per high school graduate. Rural Policy Matters. http://www.ruraledu.org/articles.php?id=2852

Rural School and Community Trust. (2010, February). A Rural Trust guide to Title I formulas. Rural Policy Matters. 
Rural School and Community Trust. (2010, May 26,). State spending averages skew Title I allocations to poor districts. Rural Policy Matters. http://www.ruraledu.org/articles.php?id=2479

Rural School and Community Trust. (2007, September 7). Rural schools-Not so much-In the middle. Rural Policy Matters. http://blog.ruraledu.org/2007/09/ruralnot_so_muchin_the_middle.html

Sherman. J., \& Sage, R. (2011). Sending off all your good treasures: Rural schools, brain-drain, and community survival in the wake of economic collapse. Journal of Research in Rural Education, 26(11). http://jrre.psu.edu/articles/26-11.pdf.

Soffer, J. M. (2010). Ed Koch and the rebuilding of New York. Columbia University Press.

Spring, J. (2005). Conflicts of interest: The politics of American education. McGraw-Hill.

Theobald, P. (1997). Teaching in the commons: Place, pride, and the renewal of community. Westview Press.

Tyack, D. (1974). The one best system: A history of American urban education. Harvard University Press.

United States Census Bureau. (2009, July) Public education finances 2007. http://www2.census.gov/govs/school/07f33pub.pdf

United States Department of Education. (2020). National blue ribbon schools program. https://www2.ed.gov/programs/nclbbrs/index.html

United States Department of Education. (2021). Every Student Succeeds Act. https://www.ed.gov/essa?src=ft

United States General Accounting Office. (2002, January). Title I funding-Poor children benefit though per poor child funding differs. https://www.gao.gov/products/gao-02-242 
W. K. Kellogg Foundation. (2001). Perceptions of rural America. http://ww2.wkkf.org/pubs/FoodRur/Pub2973.pdf

Wood, R. E. (2008). Survival of rural America: Small victories and bitter harvests. University of Kansas Press.

\section{Author biography:}

V. Sue Atkinson retired in 2020 from a career teaching and supervising programs for infants through graduate students, working with both typically developing children and students with identified disabilities at the P-12 level. At SUNY Binghamton and Cortland, she trained teachers to work with these students with an emphasis on inclusive teaching practices. Sue continues this work on an occasional basis in retirement, and writes on topics related to education, policy, child development, and disability while enjoying her rural upstate New York home and continuing to advocate for the region's schools.

Sue received her Ed.D. in Educational Theory and Practice from the State University of New York at Binghamton in 2014, and her M.S.Ed. in early childhood special education from the same university. Her B.A. in Child Study is from Tufts University. Her most recent position was Visiting Assistant Professor at Binghamton University. 
